DOI: 10.17707/AgricultForest.63.1.25

\author{
Frederico MARANGON, Lucas Emanuel SERVIDONI, \\ Carlos Wilmer COSTA, Velibor SPALEVIC, Ronaldo Luiz MINCATO ${ }^{I}$
}

\title{
LAND USE AND GROUNDWATER RESOURCES POTENTIAL VULNERABILITY TO CONTAMINATION
}

\begin{abstract}
SUMMARY
Municipality master plan approach to the expansion processes of human activities is presently essential once poor and badly planned use of natural resources cause direct or indirect impacts on the quality and quantity of groundwater resources. Concerning the problem of contamination of this resource, the analysis of land use and coverage integrated to physical variables can contribute to improve perception of the problem. In this paper, a Chart of Groundwater Resources Potential Vulnerability to Contamination at the Municipality of Alfenas $\left(849.97 \mathrm{~km}^{2}\right)$, southern Minas Gerais State, Brazil, was developed. Multicriteria analysis was applied supported by decision matrices and overlapping imagery, which classified potential vulnerability to contamination in the levels: extreme, high, moderate, low and negligible. The matrices are characterized by overlapping and comparing environmental features and human actions in Geographic Information System. Results showed that the areas classified as of moderate or extreme potential vulnerability correspond to, respectively, $51.16 \%$ and $23.38 \%$ of the study area and must be a major issue for mitigation actions of their potential vulnerabilities.
\end{abstract}

Keywords: Spatial analysis, environmental planning, soil and water conservation, geotechnologies...

\section{INTRODUCTION}

The increase of domestic, agribusiness and industrial water consumption has raised pressure on surface and underground hydric resources. Considering the economic value of water because it is essential for many species and for biogeochemical processes, proposals of sustainable water use is essential. On the other hand, inappropriate and non-planned use affects negatively quality and quantity of this resource. Besides irregular distribution, harmful changes in chemical, physical and biological characteristics of groundwaters associated to human activities in rural and urban areas are also verified.

\footnotetext{
${ }^{1}$ Frederico Marangon, Lucas Emanuel Servidoni Post-graduation Program in Environmental Science, Universidade Federal de Alfenas - UNIFAL-MG, Alfenas, Minas Gerais, BRAZIL; Carlos Wilmer Costa, Post-graduation Program in Environmental Sciences, Universidade Federal de São Carlos - UFSCAR, São Carlos, São Paulo, BRAZIL; Velibor Spalevic, University of Montenegro, Faculty of Philosophy, Department of Geography, MONTENEGRO; Ronaldo Luiz Mincato (corresponding author: ronaldo.mincato@unifal-mg.edu.br), Instituto de Ciências da Natureza - Universidade Federal de Alfenas - UNIFAL-MG, Alfenas, Minas Gerais, BRAZIL. Notes: The authors declare that they have no conflicts of interest. Authorship Form signed online.
} 
Rural areas present both diffuse impacts, due to intensive farming and cattle raising activities, and punctual or local, due to inappropriate disposal of residues and absence of basic sanitation. In urban areas, impacts are punctual and associated to illegal disposal of industrial effluents and poor sanitation services, which are absent or present precarious collection concerning treatment of drain water and discharge of residues. In Brazil, however, the concern with groundwaters contamination is limited because, in general, groundwaters's users ignore the severe effects of their pollution. This is because groundwaters contamination is not visible and exploitation is broadly shared, making the identification of the problem difficult. In general, when contamination is noticed, it has reached large extensions (Ribeiro et al., 2007). Besides, many compounds originating from polluting activities interact and are inserted as different chemicals in the hydrological cycle by natural and human processes, which may change hydrogeochemical properties of aquifers and of phreatic table water (Costa et al., 2015).

In this scenario, studies similar to those by Costa et al. (2015), which intend to explain contamination risk of groundwater resources by residues associated with human activities, are essential.

Several assessment studies of groundwaters contamination were carried out in Brazil. It is worth pointing out those of Löbler et al. (2014), which studied the municipality of Nova Palma using GOD (Groundwater occurrence, Overall lithology of the unsaturated zone, Depth to the water table) method to assess vulnerability; and, Löbler et al. (2013), which mapped groundwaters potential spots of contamination and natural vulnerability in the municipality of Restinga Seca, both in Rio Grande do Sul State. In the State of São Paulo, Cereda Junior and Röhm (2014) used multicriteria methodologies to assess environmental fragility of Rio Monjolinho basin in São Carlos Municipality. In Rondonópolis Municipality, Mato Grosso State, Cutrim and Campos (2010) estimated Furnas Aquifer vulnerability to contamination.

Therefore, the representation of vulnerability of underground hydric resources demands graphic illustration, in adequate spatial scale, physical environmental characteristics and human activities in progress there. Thus, the groundwater resources potential vulnerability to contamination by different land uses in the Municipality of Alfenas, in southern Minas Gerais State, was assessed by means of multicriteria analysis in geographic information systems (GIS).

\section{MATERIAL AND METHODS}

Alfenas, in southern Minas Gerais State, (Figure 1), is equidistant from the main metropolitan regions in Brazil: São Paulo, Rio de Janeiro and Belo Horizonte. Estimated population is of 78.712 inhabitants and it total area is of $849.97 \mathrm{~km}^{2}$ (IBGE, 2015). Climate, as per Köppen classification, is CwB (mesothermal, tropical) (Sparovek et al., 2007). 

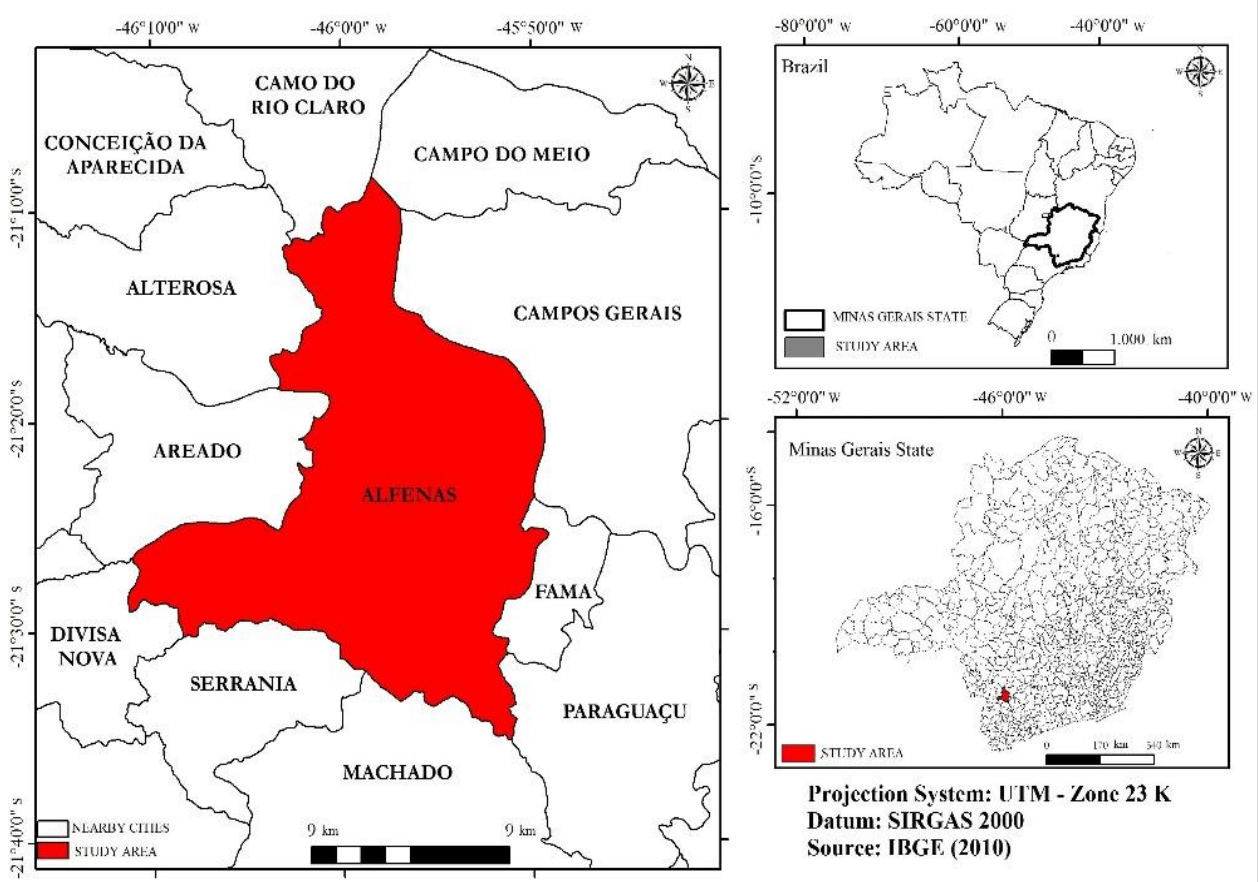

Figure 1: Site of the Study area

Alfenas is at the highlands of South of Minas Gerais or Alto Rio Grande (Ab'Saber, 1975). Altitudes vary from 760 to $960 \mathrm{~m}$, in undulating relief. The region is in the transition of 'Cerrado' (Brazilian Savannah) and 'Atlantic Forest' (Alfenas, 2006) biomes, with only small remaining fragments of natural vegetation. Farming and cattle raising activities are responsible for $15 \%$ of the municipality Gross Domestic Product - GDP (IBGE, 2012).

The geological structure is formed of charnockitic and granolithic polymetamorphic gneisses from the Precambrian period (Hasui, 2010), with complex hydrogeological domains distributed in five distinct geological units: Andrelândia and Carrancas Groups and the Campos Gerais, the VarginhaGuaxupé and the Lavras complexes (CPRM and UFRJ, 2010).

Andrelândia Group is a unit of diversified metasedimentary rocks, with predominance of quartzites in the basement followed by garnet schists, leptinites and marbles. In Alfenas Municipality, there are two types of lithofacies from the Andrelândia group (Peternel et al., 2005). The first corresponds to the association of basal lithofacies positioned discordantly, by thrust faults, onto the basement orthogneisses formed by biotite gneisses, of fine grain and thin bands. The second is concordant in relation to the biotite gneisses, formed by quartzite successions and subordinate intercalation of muscovite-quartz schists.

The Carrancas Group (FUPAI, 2013) is an alochthonous succession of metapsamitic rocks that transform into mica-graphite schists to the top, admitted 
as of Neoproterozoic passive margin of the meridional border of the Sanfranciscana Plate (Ribeiro et al., 1995).

The Basal Granulitic unit, the Intermediate Magmatitic Orthogneissic unit and the Migmatite High-grade paragneissic unit emerge in the Municipality of Alfenas from the Varginha-Guaxupé Complex. The first is formed by enderbite, granulite and mafic granulite of basement composition. The second is compound of anatexite, granitic gneiss, stromatic migmatites and tonalitic gneiss; and the third of paragneisses, mica schists and biotite gneiss (FUPAI, 2013).

The Archean terrains of the Lavras and the Campos Gerais complexes belong to the Southeastern Brazilian Gneissic-Migmatitic Archean Domain, represented by bodies of great spatial expression, intensely deformed by tectonic events. They are formed by old lithologies, as tonalitic, granitic and migmatitic orthogneisses and amphibolites (FUPAI, 2013).

Soil classes were defined as per the Soil Map of Minas Gerais State in the scale 1:650.000 (UFV et al., 2010) as: Dystrophic Red Latosol with clayey texture; Dystrophic Red-Yellow Latosol with clayey texture; Humic Dystrophic Yellow Latosol with clayey texture; typical Dystrophic Yellow Latosol with clayey texture; Dystrophic Red Argisol with medium/clayey textures; typical Eutrophic Red-Yellow Argisol with medium/clayey textures, and Dystrophic Melanic Gleysol with prominent clayey texture, plus Hydromorphic Quartzarenic Neosol, and Sapric Haplic Organosol, all field phase, flat relief.

Geographic-georeferenced information were created, developed and analysed in ArcGIS software ${ }^{\circledR}$ 10.3.1 (ESRI, 2014). Database include topographic charts of Alfenas (SF-23-I-I-3), Areado (SF-23-V-D-I-4), Campestre (SF-23-D-IV-2), Campos Gerais (SF-23-V-D-I-4), Conceição da Aparecida (SF23-V-D-I-2), and Machado (SF-23-I-III-1), all of them in the scale 1:50.000 (IBGE, 1971). Geologic charts include Alpinópolis (SF-23-V-B-IV), Machado (SF-23-V-D-V), Alfenas (SF-23-V-D-II), Guapé (SF-23-V-B-V), Campo Belo (SF-23-V-B-VI), Nepomuceno (SF-23-V-D-III), and Varginha (SF-23-V-D-VI), all of them in the scale 1:100.000 (CPRM and UFRJ, 2010).

Metadata from the Geodiversity Map of Minas Gerais State, scale 1:750,000 (CPRM, 2006), the Brazilian Hydrogeological Domains and Subdomains Map, scale 1:1,000,000 (CPRM, 2007), Soils Map of the State of Minas Gerais, scale 1:650,000 (UFV et al., 2010), imagery from Shuttle Radar Topography Mission - SRTM (Miranda, 2005), were also considered. These data and the topographic charts (IBGE, 1971) supplied altitude information in the detail compatible with the aims of the research. Slope classes were adjusted in accordance with EMBRAPA (2013). These materials were used in order to validate geological features found in the geological charts (CPMR and UFRJ, 2010). However, despite the Soils Map of the State of Minas Gerais (UFV et al., 2010), the Brazilian Hydrogeological Domains and Subdomains Map (CPRM, 2007), and the Geodiversity Map of Minas Gerais State (CPRM, 2006) being generalist, they are compatible with the aims of this work, since they allowed considering physical variables of the area. 
Land use and management mapping dated of 2015 was carried out from Landsat-8 Operational Imager OLI imagery in band 2 (green), band 4 (near infrared) and band 5 (mid infrared). Imagery was obtained from the United States Geological Survey (USGS, 2015), the United States of America. Imagery was from the dry period, which allows detailing among the following uses: perennial crops (coffee), temporary crops (sugar cane, corn, beans and soybeans), grazing areas and bare soils.

The research was developed based on the multicriteria analysis (Costa et $a l ., 2015)$, whose procedure is based on decision matrices, overlapping of images and multidisciplinary assessment of selected criteria. Selected variables were the Hydrogeological Domains Map, the Pedologic Map, the Slope Map, the Geological Faults Map and the Chart of Land Use and Management of Alfenas Municipality.

In order to assess groundwater resources potential vulnerability to contamination, multicriteria analysis is characterized by overlapping physical variables and human actions in GIS. This research model is effective in management and planning of the geographic space, in exploiting natural resources and in the conservation of soil and water (Costa et al., 2015). However, multicriteria analysis demands definition and standardization of environmental factors relevant to the subject (Valle Junior, 2015).

Multicriteria analysis has been used in studies concerning environmental planning, and should be preferred in cases in which only one variable does not represent the reality of the phenomenon (Santos, 2010). Multicriteria analysis is based on the mapping of variables by information plans and on the definition of pertinence index of each plan and of each one of their legend components for the construction of results, with the adoption of consideration factors in order to relatively assess and compare different criteria (Moura, 2014).

Thus, it is possible to carry out the analysis of the environmental variables and of the actual scenarios observed in the study area from a multi-disciplinary approach. The methodological process (Figure 2) is supported by the multicriteria analysis by overlapping imagery and decision matrices of selected variables. The procedure was carried out by setting up the database by mapping in GIS, using geoprocessing techniques.

The approach of analysis of the potential contamination was defined simultaneously with the elaboration of decision matrices. Such matrices are descriptive tables, which inform the characteristics to be overlapped in the process for each variable. Decision matrices are descriptive tables that inform the potential contamination of each attribute of the variable in relation to groundwater contamination. In the first stage, the Synthesis Map of Hydrogeological Domain Classes versus the Synthesis Map of Soil Classes were overlapped, and the first overlapping result was obtained. Then, the result of the first overlapping was geoprocessed with the third information plan, the Slope Map. 
The result of the second overlapping was geoprocessed with the Map of Productivity Classes and Geological Faults, the result of which was processed with the last variable, the Map of Land Use and Management. In short, in the GIS environment, each layer is converted into raster format and reclassified and the result of this reclassification is a new product that is used in the new overlapping.

This process is repeated to the end, by performing the last overlapping and decision matrix, which results in the Chart of Groundwater Resources Potential Vulnerability to Contamination in Alfenas - MG, as final product.

\section{RESULTS AND DISCUSSION}

In this paper, four overlappings of the groundwater resources potential vulnerability to contamination were analysed considering the levels: Extreme, High, Moderate, Low and Negligible (Foster et al., 2013).

Groundwater resources potential vulnerability to contamination maybe defined by the correlation of physical variables (Figures 2A, 2B, 2C and 2D) with classes of use and soil coverage (Figure 2E).Correlation is carried out as follows:

1) Urban area class is located on the Varginha-Guaxupé Hydrogeological complex with basal granulite Unit to the South, and the Andrelândia Group with kyanite-garnet granulites to the North. Urban area, along its history, expanded in the North-Northwest direction, moving forward onto the Hydrogeological Domain of Andrelândia Group. With approximately 1,462 ha, the urban area represents, in $2015,1.73 \%$ of the municipality. It is located on dystrophic Red Latosols of clayey texture and restrict dystrophic Melanic Gleisol, in flat to gently undulating relief $(0.00 \%$ to $3.00 \%$ and $3.00 \%$ to $8.00 \%)$.

In the analysis of the overlapped imagery of the Synthesis Map of Hydrogeological Domain Classes and the Synthesis Map of Soil Classes, it was observed that in the urban area class, the groundwater resources potential vulnerability to contamination was low to the North, and moderate to the South, a consequence of the lithologic resistance to percolation of groundwaters, and of the predominance of clayey texture soils. In overlappings number three and number four, it is shown the urban area location in the class of low hydrogeological productivity and on a geological fault, where groundwater resources potential vulnerability to contamination reached the levels high and moderate. This classification represents $4 \%$ of the high potential vulnerability illustrated in the mapping.

2)The perennial crops class, mainly the coffee crop, is homogeneously distributed in $13.36 \%$ of the municipality, covering all the hydrogeological domains, especially the Campos Gerais Complex to the North and the VarginhaGuaxupé Complex to the South. It occurs in all classes of soil in the gently undulating and undulating slopes, respectively, $3.00 \%$ to $8.00 \%$ and $8.00 \%$ to $20.00 \%$. From the first overlapping, it was observed that the class is in the moderate level $(1.67 \%)$ and low level $(0.57 \%)$ of potential vulnerability because of the lithologic characteristics of igneous and metamorphic rocks and of Clayey Soils Pedology. 


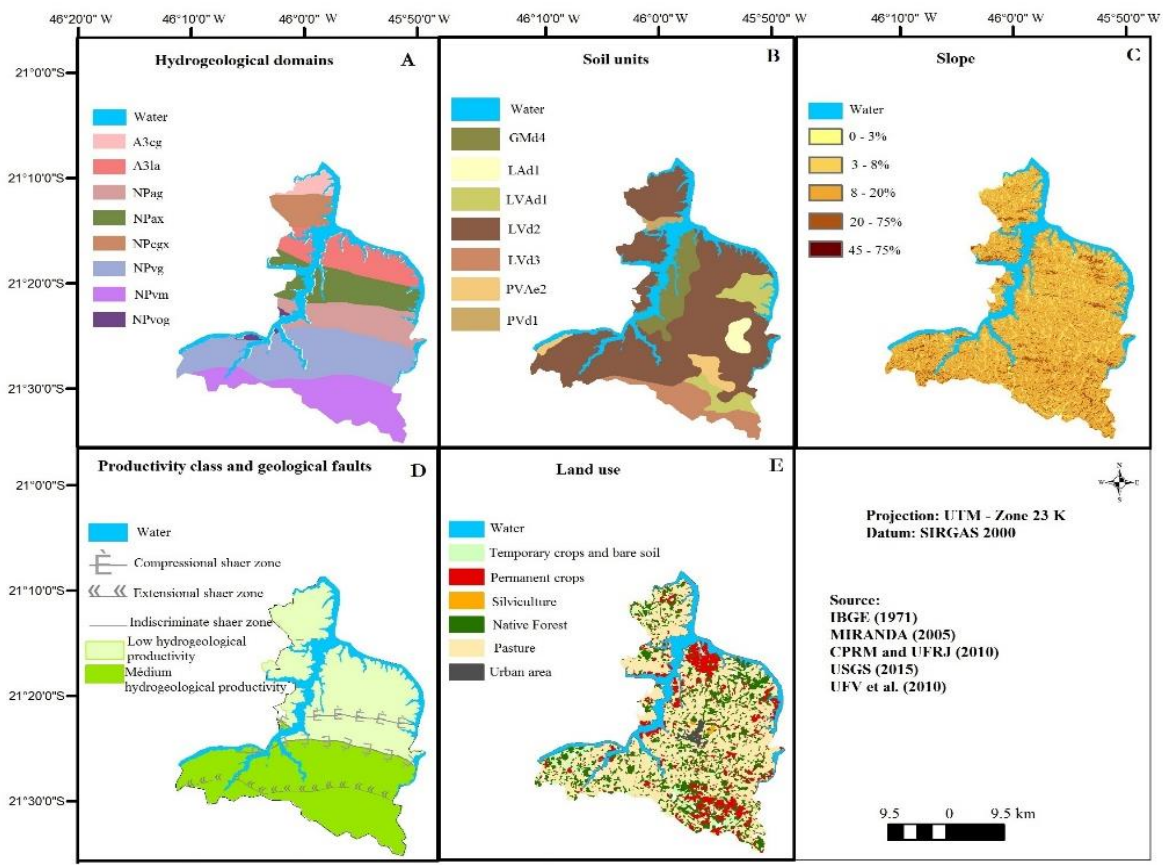

Legend: A3cg: Campos Gerais Complex; A3la: Lavras Complex; NPag and NPax: Andrelândia Group; NPcqx: Carrancas Group; NPvg, Complex NPvog and NPvm: Varginha-Guaxupé; LVd2: dystrophic Red Latosol; LVd3: dystrophic Red Latosol + dystrophic Red Yellow Latosol; LAd1: humic dystrophic Yellow Latosol + dystrophic Yellow Latosol; PVd1: dystrophic Red Argisol; PVAe2: eutrophic Red Yellow Argisol; GMd4: Melanic Gleisol + Neosol + Organosol.

Figure 2: Information plans of variables related to physical characteristics and land use.

In the second overlapping, an increase to groundwater resources potential vulnerability to contamination was diagnosed because plantations occur in gently undulating and undulating slopes, which allows a higher infiltration of water and of possible contaminants.

In overlappings three and four, agricultural practices in relation to perennial crops consume relatively fewer quantities of natural resources. However, as they are produced by conventional techniques without conservationist management, they introduce chemical elements and compounds, which may trigger important ecological unbalance, with groundwater resources potential vulnerability to contamination in the extreme and high levels. In fact, the research showed that perennial crops represent $58.93 \%$ of extreme vulnerability and $64.23 \%$ of high vulnerability at the end (Figure 3 and Table 1). 


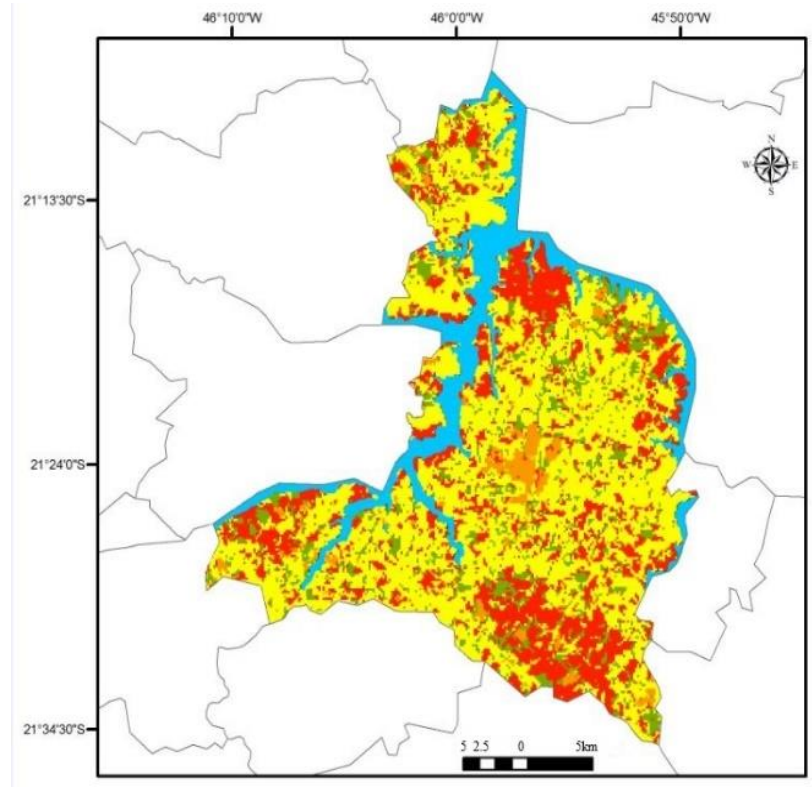

Legend

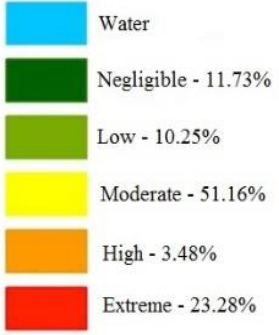

Projection: UTM - Zone 23K

Datum: SIRGAS 2000

Figure 3. Chart of Groundwater Resources Potential Vulnerability to Contamination in Alfenas - MG Municipality, showing percentage area of each vulnerability level.

The classes bare soil and prepared soil for temporary crops represent $6.21 \%$ of the area and are found in every hydrogeological domains and in every class of soil in flat relief and in gently undulating and undulating slopes. As far the potential groundwater resources vulnerability to contamination is concerned, it was observed that these classes are predominant in clayey texture soils. Soils with such characteristics result in moderate to low potential vulnerability in the first overlapping.

In the second overlapping, potential contamination reached moderate and high levels due to crops being produced in the same way as perennial crops, with conventional agricultural techniques using toxic products, without conservationist management. In the fourth overlapping, the areas with temporary crops and with bare soil next to geological faults, with low hydrogeological productivity, were in the moderate and high potential vulnerability levels.

The areas of soil prepared for temporary crops and bare soil respond to $25.25 \%$ of high potential vulnerability and $9.70 \%$ of extreme vulnerability. However, satellite imagery classification did not differentiate spectral behaviour between soil prepared for temporary crops and bare soil.

Therefore, soil prepared for temporary crops was taken for bare soil. It is in this phase that chemical elements and compounds are introduced and affect, directly or indirectly, the ecosystem balance of the areas. 
Table 1. Land use versus groundwater resources potential vulnerability to contamination: area and percentage

\begin{tabular}{|c|c|c|c|c|c|c|c|c|c|c|}
\hline $\begin{array}{c}\text { vulterability } \\
\text { Variables }\end{array}$ & $\mathrm{E}$ & $\%$ & $\mathrm{~A}$ & $\%$ & $\mathrm{M}$ & $\%$ & $\mathrm{~B}$ & $\%$ & $\mathrm{~N}$ & $\%$ \\
\hline VN & - & - & - & - & - & - & 8.56 & 96.65 & - & - \\
\hline AU & 0.21 & 0.89 & 0.33 & 4.00 & 0.37 & 0.21 & 0.42 & 1.29 & - & - \\
\hline LPS & 2.27 & 9.70 & 1.00 & 25.25 & 3.78 & 4.43 & 0.09 & 0.37 & - & - \\
\hline CT & 7.02 & 30.02 & 0.80 & 4.13 & 2.72 & 3.76 & - & - & - & - \\
\hline CP & 13.78 & 58.93 & 1.30 & 64.24 & 1.24 & 1.63 & 0.22 & 0.57 & - & - \\
\hline CA & - & - & - & - & - & - & - & - & 4.00 & 32.68 \\
\hline RHE & - & - & - & - & - & - & - & - & 7.73 & 67.32 \\
\hline AF & 0.13 & 0.76 & 0.05 & 0.38 & 1.02 & 0.94 & - & - & - & - \\
\hline AP & - & - & - & - & 42.03 & 89.03 & 0.96 & 1.12 & - & - \\
\hline AT & 194.47 & - & 29.60 & - & 87.14 & - & 87.14 & - & 103.87 & - \\
\hline T & - & 100 & - & 100 & - & 100 & - & 100 & - & 100 \\
\hline
\end{tabular}

VN: Native Vegetation; AU: Urban Area; LPS: Prepared Soil/Bare Soil; CT: Temporary Crop; CP: Perennial Crop; CA: Waterbody; RHE: Furnas Hydroelectric Reservoir; AF: Agroforest; AP: Grazing area; AT: Total Area in $\mathrm{km}^{2}$; T: Total Area in \%; Levels: E: Extreme Vulnerability; A: High Vulnerability; M: Moderate Vulnerability; B: Low Vulnerability; N: Negligible Vulnerability.

3) Consolidated temporary crops class represent $12.03 \%$ of the area and is homogeneously distributed in all variables of the studied physical structure.

In the first overlapping, it was observed that this class shows groundwater resources potential vulnerability to moderate contamination (3.76\% of the total). In the second overlapping, it was observed a predominance of these crops in flat and gently undulating slopes, which favor infiltration of possible contaminants into the soil, subsoil, and phreatic waters.

Furthermore, it was found that these crops are located on geological faults with medium hydrogeological productivity. Because of these characteristics, the class of consolidated temporary crops, which used relevant quantities of toxic products, able to impact the environmental systems, reached the extreme $(30.02 \%)$ and high $(4.13 \%)$ potential vulnerability.

4) The grazing area class is distributed in $46.32 \%$ of the municipality in all hydrogeological domains, in every class of soils, above all in the dystrophic Red Latosols and the dystrophic Red Latosol with dystrophic Red-Yellow Latosols, in all classes of slopes, with low and medium hydrogeological productivity and on geological faults.

Soil with clayey textures, when overlapped with the Lavras, Campos Gerais and Varginha-Guaxupé complexes and with the lithological features of the Carrancas and Andrelândia Groups resulted in the negligible and low levels of potential vulnerability. Further research revealed that the grazing area is associated to removal of native vegetation, which leads to changes in the soils characteristics. Thus, groundwater resources potential vulnerability to contamination of this class was in the moderate level $(89.03 \%)$. 
$5)$ The agroforest class of the study area ( $0.77 \%$ of the total) was mapped and inserted in two hydrogeological domains: The Andrelândia Group - kyanitegarnet garnulites Lower Unit, with more resistant and impermeable rocks, and on the Varginha-Guaxupé Complex - migmatitic paragneissic Upper Unit, with good permeability and secondary porosity. As far as soil classes are concerned, agroforest occurs on dystrophic Red Latosol and dystrophic Red-Yellow Latosol in gently undulating and undulating slopes far from geological faults and with medium hydrogeological productivity.

In the first overlapping, it was verified that this culture presents negligible to low groundwater resources potential vulnerability to contamination due to the predominance of more resistant and impermeable rocks and of clayey soils. In the second overlapping the moderate potential vulnerability level was reached because it is in gently undulating and undulating slopes, which favors infiltration and percolation of possible contaminants.

Now, in the third and fourth overlappings, potential vulnerability to contamination was kept in the moderate level $(0.94 \%)$, the presence of this culture being irrelevant in the high $(0.38 \%)$ and extreme $(0.76 \%)$ levels.

Native vegetation present in the area $(7.36 \%)$ is found in small fragments. This class occurs in all hydrogeological domains, soil classes, and slope degrees, and low and medium classes of hydrogeological productivity, dissociated from geological faults. In this class, the overlappings showed that $96.65 \%$ of groundwater resources potential vulnerability to contamination is low.

6) Despite waterbodies being strictly related to geological faults, which may influence the drainage and the infiltration of contaminants resulting from human activities, the Furnas Hydroelectric Reservoir and other waterbodies (12.22\% of the total) were not considered because they presented negligible groundwater resources potential vulnerability to contamination of, respectively, $67.32 \%$ and $32.68 \%$.

\section{CONCLUSIONS}

The multicriteria analysis based on GIS as integration tool of selected variables showed to be efficient for environmental planning and management.

Alfenas Municipality presents groundwater resources potential vulnerability to contamination in the extreme level (23.38\%), which results from a combination of: 1) perennial and temporary crops, 2) soils with medium clayey texture, and 3) good water storage and lithological structure transmission capacity. These factors, in combination with gently undulating and undulating slopes, with medium hydrogeological productivity and proximity to geological faults contributed with the perennial and temporary crops classes to increase potential vulnerability.

Areas in the moderate level $(51.16 \%$ of the total) of groundwater resources potential vulnerability to contamination are associated to basement crystalline rocks, which, in general, present features that prevent water infiltration and percolation. Low $(10.25 \%)$ and negligible $(11.73 \%)$ potential vulnerability areas 
are associated with undulating slopes, far from geological faults, with low hydrogeological productivity, and land use and coverage which present low potential of groundwater resources to contamination, as, for instance, grazing and agroforest areas.

Assessment of groundwater resources potential vulnerability to contamination, in Alfenas - MG, by the multicriteria analysis of physical variables and human activities was effective in generating primary and secondary knowledge about the subject. Therefore, the mapping of potential vulnerability allows planning actions in order to adjust, mitigate and manage environmental passives in areas of extreme and high potential vulnerability.

\section{ACKNOWLEDGEMENTS}

The authors are thankful to Fundação de Amparo à Pesquisa do Estado de Minas Gerais (FAPEMIG) and to Coordenação de Aperfeiçoamento de Pessoal de Nível Superior (CAPES) for the scholarships.

\section{REFERENCES}

Ab'Saber, A. N. (1975): Formas de relevo: texto básico. 80p. São Paulo: Edart.

Alfenas, Prefeitura Municipal de Alfenas. 2006. Plano Diretor de Alfenas. 189p. Alfenas: Prefeitura Municipal.

Cereda Junior, A., Röhm, S. A. (2014): Analysis of Environmental Fragility Using MultiCriteria Analysis (MCE) for Integrated Landscape Assessment. Journal of Urban and Environmental Engineering 8(1): 28-37.

Companhia de Pesquisa de Recursos Mineirais - CPRM, Universidade Federal do Rio de Janeiro - UFRJ (2010): Cartas Geológicas do Programa de Geologia do Brasil. Folhas Geológicas de Alpinópolis (SF-23-V-B-IV), Machado (SF-23-V-D-V), Alfenas (SF23-V-D-II), Guapé (SF-23-V-B-V), Campo Belo (SF-23-V-B-VI), Nepomuceno (SF23-V-D-III) e Varginha (SF-23-V-D-VI). Escala: 1:100.000. Brasília: CPRM.

Companhia de Pesquisa de Recursos Mineirais - CPRM. (2007): Mapa de domínios e subdomínios hidrogeológicos do Brasil. Escala: 1: 2.500.000. Projeto SIG de Disponibilidade Hídrica do Brasil (SDHB). Brasília: CPRM.

Costa, W. C., Cançado, C., Moraes, M. P., Marangon, F., Guerrero, J. V. R., Lorandi, R., Lollo, R., Moschini, L. E. (2015): Potencial de Contaminação de Aquíferos da Bacia do Ribeirão do Meio - Município de Leme - SP. Revista Brasileira de Recursos Hídricos 20(1): 218-225.

Cutrim, A. O., Campos, J. E. G. (2010): Avaliação da vulnerabilidade e perigo à contaminação do aquífero Furnas na cidade de Rondonópolis (MT) com aplicação dos métodos GOD e POSH. Rio Claro: Geociências, 29(3): 401-411.

Ducci, D., Sellerino, M. (2013): Vulnerability mapping of groundwater contamination based on 3D lithostratigraphical models of porous aquifers. Science of Total Environmental 447: 315-322.

Empresa Brasileira de Pesquisa Agropecuária - EMBRAPA (2013): Sistema Brasileiro de Classificação de Solos. 3.ed. 412p. Rio de Janeiro: EMBRAPA.

Environmental Systems Research Institute - ESRI (2014): ArcGIS for the desktop 10.3.1.

Fundação de Pesquisa e Assessoramento à Indústria - FUPAI (2013): Plano Diretor de Recursos Hídricos da Bacia Hidrográfica do Entorno do Lago de Furnas: Relatório 1 Diagnóstico da Bacia Hidrográfica. 305p. Itajubá: FUPAI.

Foster, S., Hirata, R., Andreo B. (2013): The aquifer pollution vulnerability concept: aid or impediment in promoting groundwater protection? Hydrogeology Journal 21: 13891392.

Hasui, Y. (2010): A grande colisão pré-cambriana do Sudeste Brasileiro e a estruturação regional. Rio Claro: Geociências 29(2): 141-169. 
Instituto Brasileiro de Geografia e Estatística (IBGE). 1971. Cartas Topográficas: Folhas Topográficas de Alfenas (SF-23-I-I-3), Areado (SF-23-V-D-I-4), Campestre (SF-23V-D-IV-2), Campos Gerais (SF-23-V-D-I-4), Conceição da Aparecida (SF-23-V-D-I2) e Machado (SF-23-I-III-1). Escala 1:50.000.

Instituto Brasileiro de Geografia e Estatística - IBGE (2015): Estimativas da População Residente nos Municípios Brasileiros com Data de Referência em $1^{\circ}$ de julho de 2015.

Instituto Brasileiro de Geografia e Estatística - IBGE (2012): Produção Agrícola Municipal, v.38, 97p. Rio de Janeiro: IBGE.

Löbler, C. A., Terra, L. G., Silva, J. L. S. 2014. Dados da CPRM/SIAGAS e imagens SRTM como base cartográfica na elaboração de mapeamento em recursos hídricos subterrâneos em escala municipal: o caso de Nova Palma, RS. Pernambuco: Revista Brasileira de Geografia Física 7(3): 513-523.

Löbler, C. A., Silva, J. L. S., Martelli, G. V., Ertel, T. (2013): Pontos Potenciais de Contaminação e Vulnerabilidade Natural das Águas Subterrâneas do Município de Restinga Seca - RS. Pernambuco: Revista Brasileira de Geografia Física 6(3): 500509.

Miranda, E. E. (2005): Brasil em Relevo. Campinas: Embrapa Monitoramento por Satélite. Available: <http://www.relevobr.cnpm.embrapa.br> Acess in: December 20 of 2015.

Moura, A. C. M. (2014): Geoprocessamento na Gestão e Planejamento Urbano. 3.ed. 312p. Rio de Janeiro: Interciência.

Peternel, R., Trouw, R. A. J., Schmitt, R. S. (2005): Interferência entre duas faixas móveis Neoproterozoicas: O caso das Faixas Brasília e Ribeira no Sudeste do Brasil. São Paulo: Revista Brasileira de Geociências 3(35): 297-310.

Ribeiro, M. L., Lourencetti, C., Pereira, S. Y., Marchi, M. R. R. (2007): Contaminação de águas subterrâneas por pesticidas: avaliação preliminar. São Paulo: Química Nova 30(3): 688-694.

Ribeiro, A., Andreis, R. R., Trouw, R. A. J., Paciullo, F. V. P., Valença, J. G. (1995): Evolução das bacias proterozóicas e o termo-tectonismo brasiliano na margem sul do Cráton do São Francisco. São Paulo: Revista Brasileira de Geociências 24(4): 235-248.

Santos, A. A. (2010): Geoprocessamento aplicado à identificação de áreas de fragilidade ambiental no parque estadual da Serra do Rola Moça. (Especialização em Geoprocessamento) 39p. Belo Horizonte: UFMG.

Santos, A. P., Rocha, S. F., Abreu, M. V. S., Calijuri, M. L., Santos, P. M. (2012): O uso da análise multicritério no mapeamento da fragilidade social da área urbanizada do Município de Viçosa - MG. Rio de Janeiro:Revista Brasileira de Cartografia 64(5): 635-643.

Sparovek, G., Lier, Q. J. V., Dourado Neto, D. (2007): Computer assisted Köppen climate classification: case study for Brazil. Internacional Journal of Climatology 27(2): $257-$ 266.

United States Geological Survey (USGS). Landsat_8. Scene: LC82190752015314LGN00. Available: <http://earthexplorer.usgs.gov/> Acess in: January 23 of 2014.

Universidade Federal de Viçosa (UFV); Fundação Centro Tecnológico de Minas Gerais (CETEC); Universidade Federal de Lavras (UFLA) e Fundação Estadual de Meio Ambiente (FEAM). (2010): Mapa de Solos do Estado de Minas Gerais. 49p. Belo Horizonte. FEAM, Available: <http://www.feam.br/noticias/1/949-mapas-de-solo-doestado-deminas-gerais>. Acess: June 03 of 2014.

Valle Junior, R. F., Varandas, S. G. P., Fernandes, L. F. S., Pacheco, F. A. L. (2015): Multi Criteria Analysis for the monitoring of aquifer vulnerability: A scientific tool in environmental policy. Environmental Science Polici 48: 250-264. 